\title{
Evaluating the suitability of groundwater for irrigational purposes in some selected districts of the Upper West region of Ghana
}

\author{
Musah Salifu $^{1} \cdot$ Felix Aidoo $^{1} \cdot$ Michael Saah Hayford $^{1} \cdot$ Dickson Adomako $^{2} \cdot$ \\ Enoch Asare ${ }^{3}$
}

Received: 9 May 2014/Accepted: 27 February 2015/Published online: 17 March 2015

(C) The Author(s) 2015. This article is published with open access at Springerlink.com

\begin{abstract}
Groundwater is a very important asset to the people of the Upper West region of the Ghana where majority of them are farmers. Groundwater serves as the most reliable source of water for their domestic and agricultural activities. This study was aimed at assessing the suitability of groundwater for irrigational purposes in some selected communities of five districts where farming activities are very intensive. Twenty-three groundwater samples were collected and analysed for major anions and cations. Physicochemical parameters such as electrical conductivity (EC) and total dissolved solids (TDS) were also measured. From the results of the analyses and measurements, the suitability of the groundwater for irrigation were evaluated based on the TDS, EC, percentage sodium $(\% \mathrm{Na})$, sodium adsorption ratio (SAR), permeability index (PI), residual sodium carbonate (RSC), magnesium adsorption ratio (MAR), Kelly's ratio (KR) and chloro-alkaline Indices (CAI). US salinity laboratory diagram and Wilcox diagrams were also applied. The EC results show that the groundwater in the study area can be classified as none and slight to moderate. According to the US salinity diagram, groundwater in the study area falls within the low salinity-low sodium hazard and medium salinity-low sodium hazard class. The $\% \mathrm{Na}$ and the resulting Wilcox diagram also classify the groundwater as excellent to good
\end{abstract}

Musah Salifu

geomoba2003@yahoo.com

1 National Nuclear Research Institute, Ghana Atomic Energy Commission, Legon, P. O. Box LG80, Accra, Ghana

2 Ghana Space Science and Technology Institute, Ghana Atomic Energy Commission, Legon, P. O. Box LG80, Accra, Ghana

3 Water Resources Commission, Accra, Ghana and good to permissible. The groundwater in the study area is generally good for irrigation purposes. However, there are few instances which are problematic and would require special irrigation methods.

Keywords Groundwater · Upper West region · Irrigation - Farming $\cdot$ Sodium adsorption ratio

\section{Introduction}

The Upper West region is one of the major food baskets of Ghana where majority of foodstuffs are cultivated annually for the sustenance of its indigenes and the country as a whole. The region forms part of the Sahelian region of Ghana and is characterized by a precarious nature of surface water reserves. In many places, the aquifers are the only continuous source of water available to meet the needs of the inhabitants. The spatial and temporal variability of water resources in sub-Saharan Africa is influencing agricultural development and this can ultimately affect food insecurity and poverty in the region (Anayah and Kaluarachchi 2009).

Rainfall still remains the main source of water for agriculture in the Upper West region and the nation as a whole. Surface water resources such as rivers also play important roles in this regard. The construction of irrigation dams in various parts of the region to serve as reservoirs for use in the dry season attests to the over dependency on rainfall for agriculture. In recent years, however, the negative effects of climate change have led to changes in rainfall patterns and intensity. The lengthy dry season has also resulted in the drying up of various surface waters and dams in the region. This has made the construction of dams 
for irrigation purposes not too useful and has led to low harvest in some seasons. In addition, surface water bodies are highly vulnerable to contamination due to natural alteration and anthropogenic interference. This makes them potentially not suitable for irrigation. Notwithstanding this, the Government of Ghana through the Ministry of Food and Agriculture and other development partners are still placing increased attention on irrigation as a way to increase output, address food and nutrition security, and alleviate poverty (Namara et al. 2011).

The increasing potential of groundwater resources in the region has been underestimated. Due to the wrong notion that the groundwater resources of the region are relatively inadequate, its usage has been restricted to domestic purposes. The fallen water tables in some areas where many boreholes have been sited further augments this notion as has been reported by Gyau-Boakye and Tumbulto (2000). This has relegated the use of groundwater as a potential and reliable source of water for irrigation.

However, in recent times, the use of groundwater for irrigation in other parts of the country such the Upper East, Volta and Greater Accra Regions of Ghana (Namara et al. 2011; Kortatsi 1994) has resulted in farmers in the Upper West region also taken a queue from that. According to Yidana and Yidana (2009), it has been envisaged that groundwater has the potential of being phased in sufficient quantities to meet irrigation needs to raise the living standards of the communities whose main stay over the years has been rain-fed peasant farming.

The quality of groundwater is very crucial for the sustainability of life. Groundwater is generally assumed to be safe for consumption because it is located beneath the land surface and not typically in contact with the atmosphere (Quist et al. 1988). Although groundwater is generally buffered from most surface polluting activities (Yidana and Yidana 2009), its quality can further deteriorate with time as a result of increasing pollution of surface water. Groundwater quality may also be compromised as a result of anthropogenic activities close to boreholes and shallow hand dug wells. Poor sanitation, improper waste disposal, seepage of agrochemicals and mining has been observed to affect the quality of groundwater (Salifu et al. 2013; Fianko et al. 2010; Jain et al. 2009; Carpenter et al. 1998). Sustaining current agricultural production and agri-food processing depends on quality water supplies. Irrigation requires good quality water in order to prevent damage to sensitive crops from pesticides, salts, and trace metals (Kurdi et al. 2013). In addition, low sodicity in irrigation waters is necessary to maintain soil structural stability (Little et al. 2010). This study seeks to evaluate the quality and suitability of groundwater as an alternate source of water for irrigation in some selected districts of the Upper West region of Ghana.

\section{Study area}

\section{Location and geography}

The region covers a geographical area of approximately $18,478 \mathrm{~km}^{2}$. This constitutes about $12.7 \%(12 \%)$ of the total land area of Ghana. The region is bordered on the North by the Republic of Burkina Faso, on the East by Upper East Region, to the South by Northern Region and on the West by Cote d'Ivoire. It is the seventh largest region in Ghana in total area, and is made up of nine districts. The major economic activity of the region is agriculture. Crops grown include corn, millet, peanuts, ocra, shea butter, yam and rice. Sheep, goats, chickens, pigs and guinea fowls are raised for meat and eggs (http://www. ghanadistricts.com/reg-info.asp?RegionID=6). Five districts were selected for this study and the selected towns are those noted for intensive agricultural activities.

Because the region's dry season is long, extending roughly from October to May, many people leave the region to work in the Southern part of Ghana for at least part of the year. The region is located in the Guinea Savannah vegetation belt. The vegetation consists of grass with scattered drought-resistant trees such as the shea, the baobab, dawadawa, and neem trees. The heterogeneous collection of trees provides all domestic requirements for fuel wood and charcoal, construction of houses, cattle kraals and fencing of gardens. The shorter shrubs and grass provide fodder for livestock. The climate of the region is one that is common to the three Northern regions. There are two seasons, the dry and the wet seasons. The wet season commences from early April and ends in October. The dry season, which is characterized by the cold and hazy harmattan (the North East trade winds) weather, starts from early November and ends in the latter part of March when the hot weather begins with intensity and ends only with the onset of the early rainfall in April. The temperature of the region is between a low of $15^{\circ} \mathrm{C}$ at night time during the harmattan season and a high of $40{ }^{\circ} \mathrm{C}$ in the day during the hot season (http://www.ghanadistricts.com/ reg-info.asp?RegionID=6). Total annual rainfall in the area ranges from 910 to $2000 \mathrm{~mm}$ with an average humidity of $95 \mathrm{~mm}$ (Aduah and Aabeyir 2012).

\section{Geology}

The study area falls within the Wa-Lawra Gold belt of Ghana. This is a unique belt as it is the only Birimian Goldbearing belt in Ghana which trends in the North-South direction. There remaining Gold-bearing belts all trend in the North East-South-West directions. The Wa-Lawra belt 
marks the eastern side of a much larger, $\mathrm{N}-\mathrm{S}$ trending greenstone belt that extends into Gaoua area of Burkina Faso, well west of the Black Volta (Kesse 1985; Griffis and Agezo 2000). The geology of the study area is mainly the basement crystalline rocks associated with the West African Craton. The geology of the Wa-Lawra belt has been described by several workers including Leube et al. (1990), Taylor et al. (1992), and Hirdes and Davis (1992). The basement crystalline rocks are of Precambrian age and basically consist of the Birimian rocks and associated granitoid intrusions. These rocks include biotite and muscovite-bearing granite, hornblende-bearing granite, granodiorite, diorite and gabbro, phyllites, schist, tuffs, basalt, sandstones, siltstones, manganiferous sediments and strongly deformed metamorphic rocks (Key 1992; Nude and Arhin 2009) (Fig. 1).

\section{Sampling and analysis}

A total of 23 groundwater samples, namely, monitoring, domestic and hand dug wells from five districts were sampled. The sampling campaign was carried out in the dry season, in the months of October and November, 2013. In sampling from boreholes with hand pumps, purging was done for a minimum of $10 \mathrm{~min}$ to flush stagnant water retained in the pipes. In the case of hand dug wells, it was properly checked and confirmed that the well was being used daily. This was to ensure that stale and stagnant water was not sampled. All the water samples were collected in $250 \mathrm{~mL}$ preconditioned high-density polyethylene bottles. The bottles were conditioned by washing with $5 \%$ nitric acid, and then rinsed several times with distilled water. This was carried out to ensure that the sampling bottles were free from contaminants. Temperature, electrical conductivity (EC) and total dissolved solids (TDS) measurements were conducted in situ in the field by the HACH conductivity and $\mathrm{pH}$ meter. Onsite testing of these variables was necessary since these parameters are likely to change during transport. Bicarbonate $\left(\mathrm{HCO}_{3}{ }^{-}\right)$titration was done at the well head using a $\mathrm{HACH}$ digital titrator. Sodium $\left(\mathrm{Na}^{+}\right)$and potassium $\left(\mathrm{K}^{+}\right)$were analysed using flame emission photometer (Sherwood model 420), magnesium $\left(\mathrm{Mg}^{2+}\right)$ and calcium $\left(\mathrm{Ca}^{2+}\right)$ using Varian AA240 Fast Sequential Atomic Absorption Spectrometer. Chloride $\left(\mathrm{Cl}^{-}\right)$, sulphate $\left(\mathrm{SO}_{4}{ }^{2-}\right)$ and nitrate $\left(\mathrm{NO}_{3}{ }^{-}\right)$were analysed using ICS-90 ion chromatography at the Nuclear Chemistry and Environmental Research Centre, Ghana Atomic Energy Commission.

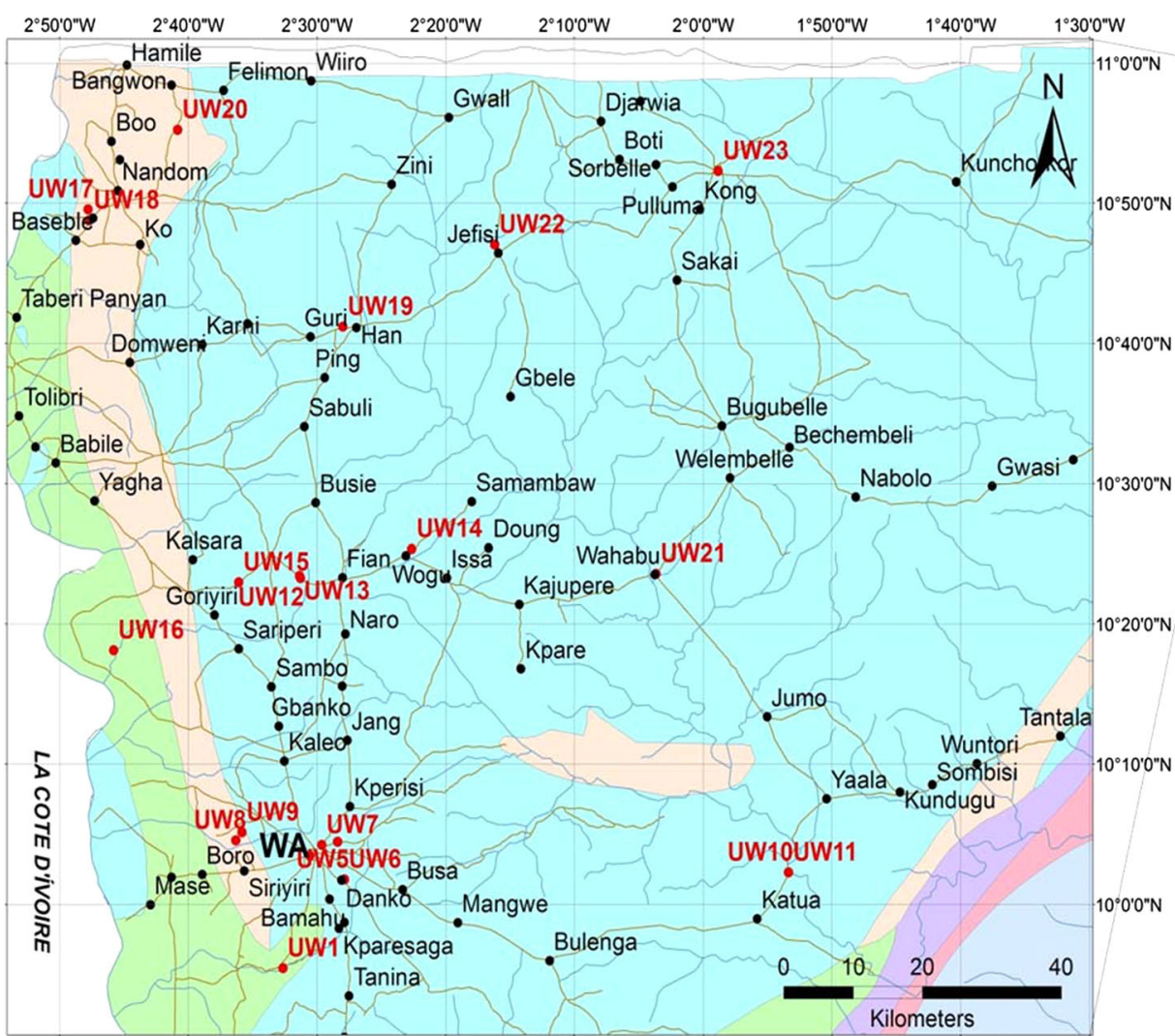

Fig. 1 Geological map of the study area showing the sampling points
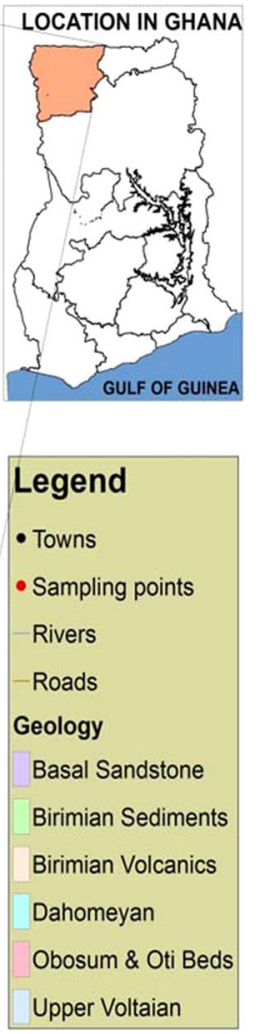


\section{Quality of irrigation water}

The concentration and composition of dissolved constituents in water determine its quality for irrigation use. Quality of water is an important consideration in any appraisal of salinity or alkali conditions in an irrigated area (USSL 1954). Water used for irrigation can vary greatly in quality depending upon type and quantity of dissolved salts. Salts are present in irrigation water in relatively small but significant amounts. They originate from dissolution or weathering of the rocks and soil, including dissolution of lime, gypsum and other slowly dissolved soil minerals. These salts are carried with the water to wherever it is used. In the case of irrigation, the salts are applied with the water and remain behind in the soil as water evaporates or is used by the crop. The suitability of water for irrigation is determined not only by the total amount of salt present, but also by the kind of salt. Various soil and cropping problems develop as the total salt content increases, and special management practices may be required to maintain acceptable crop yields. Water quality or suitability for use is judged on the potential severity of problems that can be expected to develop during long-term use (Ayers and Westcott 1985).

The characteristics of irrigated water that makes it very important in determining its quality are the total concentration of soluble salts (TDS), relative proportion of sodium to other cations (sodium adsorption ratio, SAR), chemical concentration of elements like $\mathrm{Na}^{+}, \mathrm{Cl}^{-}$and/or B that may be toxic and residual sodium carbonate or residual alkalinity (RSC or RA) (Michael 1992; Raghunath 1987; USGS 1948). Various criteria have been used in literature in the classification of groundwater for irrigation purposes. These include:

1. The sodium adsorption ratio (SAR) proposed by the Richards (1954) and defined as:

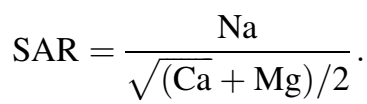

SAR gives an indication of the level to which irrigation water undergoes cation exchange reaction in soil.

2. Soluble sodium percent (SSP) is also used to evaluate sodium hazard. Doneen (1964) defines SSP as:

$\mathrm{SSP}=\frac{\mathrm{Na}^{+}+\mathrm{K}^{+}}{\mathrm{Na}^{+}+\mathrm{Ca}^{2+}+\mathrm{Mg}^{2+}+\mathrm{K}^{+}} \times 100$.

Water with an SSP greater than $60 \%$ may result in sodium accumulations that will cause a breakdown in the soil's physical properties.

3. Residual alkalinity (RA) or residual sodium carbonate (RSC) defined by Eaton (1950) and Richards (1954):

$$
\mathrm{RSC}=\left(\mathrm{HCO}_{3}^{-}+\mathrm{CO}_{3}\right)-\left(\mathrm{Ca}^{2+}+\mathrm{Mg}^{2+}\right) .
$$

4. Kelly's ratio defined by Kelly (1963) as

$\mathrm{KR}=\frac{\mathrm{Na}^{+}}{\mathrm{Ca}^{2+}+\mathrm{Mg}^{2+}}$.

5. Magnesium adsorption ratio (MAR) which was proposed by Raghunath (1987) as: $\mathrm{Na}^{+}$

$\mathrm{MAR}=\frac{\mathrm{Mg}^{2+}}{\mathrm{Ca}^{2+}+\mathrm{Mg}^{2+}} \times 100$.

6. Doneen (1964) also classified irrigated water based on permeability index $(\mathrm{PI})$ as:

$P I=\frac{\mathrm{Na}^{+}+\sqrt{\mathrm{HCO}_{3}}}{\sqrt{\mathrm{Na}^{+}}+\mathrm{Mg}^{2+}+\mathrm{Ca}^{2+}} \times 100$.

7. Chloro-alkaline indices (CAI) defined as:

$\mathrm{CAI}-\mathrm{I}=\frac{\left[\mathrm{Cl}^{-}-\left(\mathrm{Na}^{+}+\mathrm{K}^{+}\right)\right]}{\mathrm{Cl}^{-}}$.

All ionic concentrations are in milli-equivalents per litre (meq/L) except for Na\%, MAR and PI which are expressed in percentages.

\section{Results and discussion}

The hydrochemical dataset resulting from the 23 samples are presented in the form of box plots and table in Fig. 2 and Table 1, respectively. Table 2 presents the calculated irrigation water quality parameters. There are variations in the data of each parameter as indicated by the position of the median bar and the relative lengths of the whiskers on both sides of the box (Fig. 2) of each of the parameters. Most of the parameters have low concentrations and may be indicative of natural processes such as water-rock interactions controlling the chemistry of groundwater in the study area.

The $\mathrm{pH}$ of the groundwater in the study area ranges from 6.3 to 8.1 indicating that the waters are slightly acidic to slightly basic. The highest $\mathrm{pH}$ value was recorded in the Wa municipality with Uwollu in the Nadowli district having the least $\mathrm{pH}$ value. The total dissolved solids (TDS) shows wide variations, ranging between 43.8 to $564 \mathrm{mg} / \mathrm{L}$ with a mean concentration of $211 \mathrm{mg} / \mathrm{L}$. All the groundwaters have TDS values within the WHO (2005) acceptable limits of $1500 \mathrm{mg} / \mathrm{L}$. The electrical conductivities also portray wide variations, ranging in value from 87.5 to $1128 \mu \mathrm{S} / \mathrm{cm}$. The higher EC recorded in some groundwaters in the study area indicates the enrichment of some salts in the groundwater. The value of electrical conductivity may be an approximate index of the total content of dissolved substance in water. Their presence depends upon temperature, concentration and types of ions present (Hem 

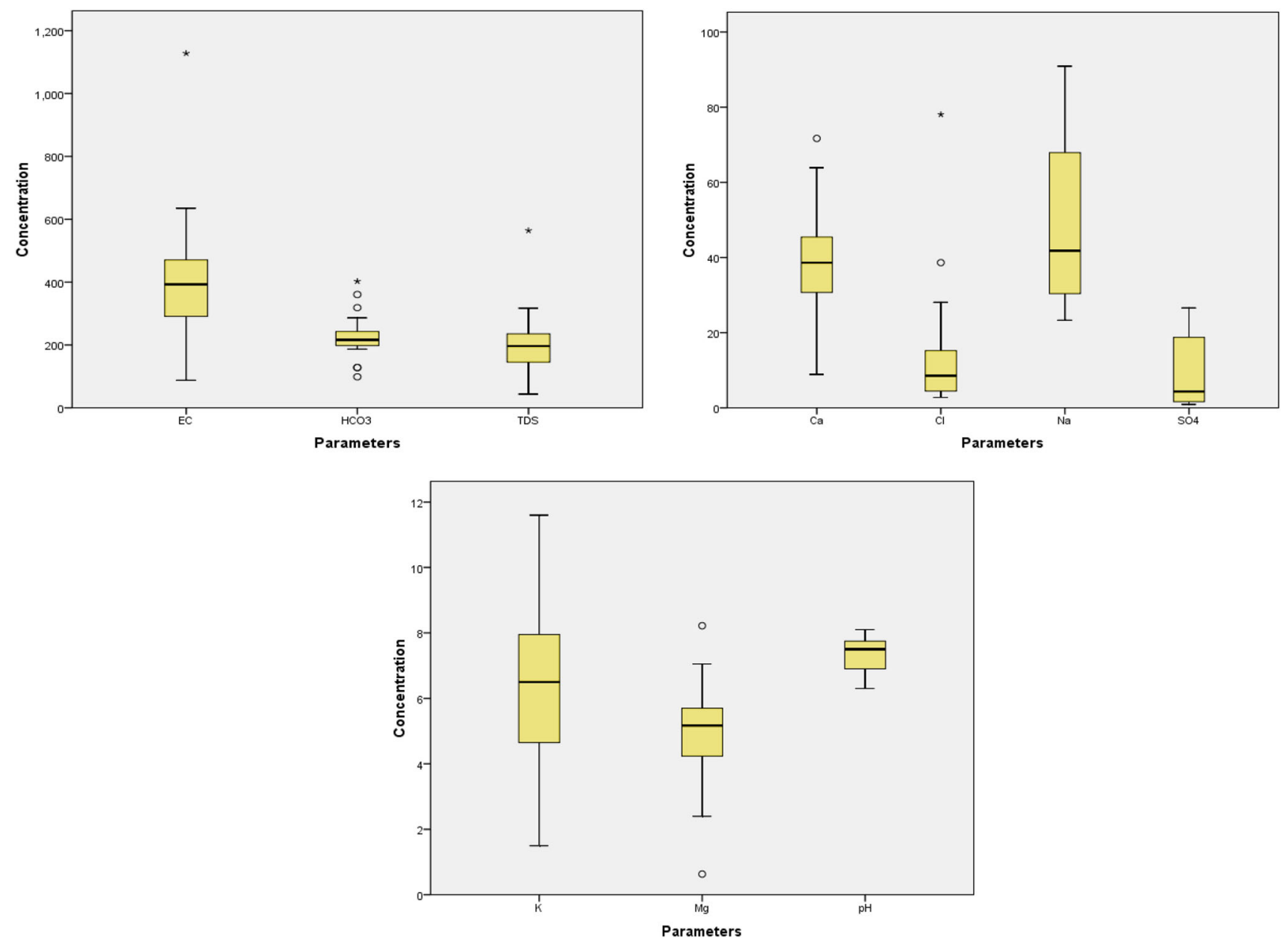

Fig. 2 Box plots representing the statistical summaries of the hydrochemical data of each parameter used for this study

1985). Only a domestic well in Jeffisi-Bosobelle of the Sissala district recorded EC value above the acceptable permissible limit of $1500 \mu \mathrm{S} / \mathrm{cm}$ (WHO 2005).

The $\mathrm{HCO}_{3}{ }^{-}$value ranges from 98.8 to $402.6 \mathrm{mg} / \mathrm{L}$. All but one sample has its $\mathrm{HCO}_{3}{ }^{-}$concentrations exceeding the $380 \mathrm{mg} / \mathrm{L}$ standard set by the WHO (2005). $\mathrm{Ca}^{2+}$ values vary between 8.91 and $71.67 \mathrm{mg} / \mathrm{L}$ with an average value of $38.97 \mathrm{mg} / \mathrm{L} . \mathrm{Mg}^{2+}$ concentrations also range from 0.63 to $8.22 \mathrm{mg} / \mathrm{L}$. $\mathrm{Ca}^{2+}$ and $\mathrm{Mg}^{2+}$ have all their concentrations within the WHO (2005) acceptable limits of 200 and $150 \mathrm{mg} / \mathrm{L}$, respectively. Crops grown on soils having an imbalance of calcium and magnesium may exhibit toxic symptoms.

$\mathrm{Na}^{+}$concentration in groundwater in the study area ranges from 23.3 to $90.90 \mathrm{mg} / \mathrm{L}$. The mean value is $49.42 \mathrm{mg} / \mathrm{L}$. $\mathrm{K}^{+}$values also range between 1.5 and $11.6 \mathrm{mg} / \mathrm{L}$. All the $\mathrm{Na}^{+}$and $\mathrm{K}^{+}$concentrations are within acceptable limits. High concentrations of $\mathrm{K}^{+}$may introduce a magnesium deficiency and iron chlorosis. An imbalance of $\mathrm{Mg}^{2+}$ and $\mathrm{K}^{+}$may be toxic, but the effects of both can be reduced by high calcium levels (Fipps 2003).
$\mathrm{SO}_{4}{ }^{2-}$ concentrations also returned values within the acceptable limit of $200 \mathrm{mg} / \mathrm{L}$ set by the WHO (2005). $\mathrm{SO}_{4}{ }^{2-}$ salts affect sensitive crops by limiting the uptake of calcium and increasing the adsorption of sodium and potassium, resulting in a disturbance in the cationic balance within the plant.

\section{Irrigational water quality}

\section{Electrical conductivity (EC)}

EC which gives an indication of the salinity hazard is the most important water quality guideline on crop productivity (Johnson and Zhang 1990). Water with high salinity is toxic to plants and poses a salinity hazard (Fipps 2003). According to Ayers and Westcott (1985), groundwater with an EC value greater than $3000 \mu \mathrm{S} / \mathrm{cm}(>3000 \mu \mathrm{S} / \mathrm{cm})$ is termed "Fair" and would greatly affect crop productivity or yield. The water is termed "Good" if the EC ranges between 700 and $3000 \mu \mathrm{S} / \mathrm{cm}$ while "Excellent" refers to waters with EC values less than $700 \mu \mathrm{S} / \mathrm{cm}(<700 \mu \mathrm{S} / \mathrm{cm})$. 
From the classification suggested by Ayers and Westcott (1985), groundwaters in the study area can be termed as "Excellent" and "Good". This result may be a reflection of the satisfactory crop productivity in the study area. High $\mathrm{EC}$ water results in the inability of plants to compete for ions in the soil, resulting in physiological drought and subsequently decreasing the crop yield. This means that even though the field appears to have plenty of moisture,

Table 1 Statistical summary of the physicochemical parameters in the study area

\begin{tabular}{llll}
\hline Parameter & Minimum & Maximum & Mean \\
\hline Temperature & 26.9 & 31.5 & 30.1 \\
pH & 6.3 & 8.1 & 7.3 \\
TDS & 43.8 & 564.0 & 211.0 \\
EC & 87.5 & 1128.0 & 422.2 \\
$\mathrm{Ca}^{2+}$ & 8.91 & 71.67 & 38.97 \\
$\mathrm{Mg}^{2+}$ & 0.63 & 8.22 & 4.95 \\
$\mathrm{Na}^{+}$ & 23.30 & 90.90 & 49.42 \\
$\mathrm{~K}^{+}$ & 1.50 & 11.60 & 6.17 \\
$\mathrm{Cl}^{-}$ & 2.78 & 78.05 & 16.09 \\
$\mathrm{HCO}_{3}^{-}$ & 98.80 & 402.60 & 227.04 \\
\hline
\end{tabular}

the plants wilt because of the inability of the roots to absorb water (Fipps 2003).

\section{Total dissolved solids (TDS)}

In the assessment of the quality of groundwater for irrigation, TDS is one of the very important parameters considered. This has become necessary due to the presence of toxic solid particles in the water (Matthess 1982). A salinity problem exists if salt accumulates in the crop root zone to a concentration that causes a loss in yield. In irrigated areas, these salts often originate from a saline, high water table or from salts in the applied water. Yield reductions occur when the salts accumulate in the root zone to such an extent that the crop is no longer able to extract sufficient water from the salty soil solution, resulting in a water stress for a significant period of time. If water uptake is appreciably reduced, the plant slows its rate of growth (Ayers and Westcott 1985). Waters with TDS values less than $450 \mathrm{mg} / \mathrm{L}(<450 \mathrm{mg} / \mathrm{L})$ are termed "None" and considered suitable or good for irrigation. Those with TDS values between 450-2000 mg/L and greater than $2000 \mathrm{mg} / \mathrm{L}$ (>2000 mg/L) represent "Slight to Moderate" and "Severe", respectively (Ayers and Westcott 1985; UCCC 1974). Groundwaters in the study

Table 2 Calculated irrigation water quality parameters of groundwater samples in the study area

\begin{tabular}{|c|c|c|c|c|c|c|c|c|c|c|c|}
\hline Community & District & Sample ID & TDS & EC & SAR & $\% \mathrm{Na}$ & KR & PI & RSC & MAR & CAI \\
\hline Siiru & Wa & UW1 & 152.8 & 306.0 & 1.74 & 47.5 & 0.82 & 88.82 & 0.96 & 15.39 & -5.54 \\
\hline Wa & Wa & UW2 & 122.4 & 245.0 & 1.36 & 41.46 & 0.62 & 87.87 & 1.26 & 18.13 & -4.57 \\
\hline $\mathrm{Wa}$ & Wa & UW3 & 87.3 & 174.5 & 1.26 & 47.84 & 0.79 & 99.07 & 0.83 & 18.36 & -3.92 \\
\hline $\mathrm{Wa}$ & Wa & UW4 & 87.3 & 174.5 & 1.28 & 48.4 & 0.8 & 99.7 & 0.84 & 15.73 & -3.96 \\
\hline $\mathrm{Wa}$ & Wa & UW5 & 160.5 & 321.0 & 1.42 & 44.28 & 0.71 & 94.7 & 1.3 & 23.07 & -19.23 \\
\hline $\mathrm{Wa}$ & Wa & UW6 & 160.5 & 321.0 & 1.46 & 44.83 & 0.73 & 95.17 & 1.31 & 22.2 & -17.7 \\
\hline $\mathrm{Wa}$ & Wa & UW7 & 105.3 & 211.0 & 1.44 & 42.84 & 0.72 & 93.72 & 1.1 & 17.36 & -2.56 \\
\hline Silaa & Wa & UW8 & 253.0 & 506.0 & 3.85 & 66.06 & 1.88 & 99.44 & 3.83 & 20.31 & -32.95 \\
\hline Silaa Duasi & Wa & UW9 & 277.0 & 555.0 & 3.37 & 61.29 & 1.55 & 98.4 & 2.86 & 18.95 & -17.1 \\
\hline Yanyounyiri & Wa & UW10 & 210.0 & 421.0 & 2.59 & 52.62 & 1.14 & 87.42 & 0.97 & 19.87 & -5.4 \\
\hline Yanyounyiri & Wa & UW11 & 210.0 & 421.0 & 2.6 & 54.81 & 1.16 & 88.03 & 1.03 & 19.31 & -4.87 \\
\hline Uwollo & Nadowli & UW12 & 161.8 & 324.0 & 0.99 & 33.97 & 0.43 & 79.46 & 0.79 & 15.18 & -2.25 \\
\hline Uwollo & Nadowli & UW13 & 177.9 & 356.0 & 1.01 & 32.09 & 0.4 & 75.02 & 0.98 & 14.3 & -2.32 \\
\hline Wogu-Newtown & Nadowli & UW14 & 196.4 & 393.0 & 3.15 & 58.93 & 1.4 & 89.32 & 1.05 & 26.86 & -0.66 \\
\hline Moyiri & Nadowli & UW15 & 317.0 & 635.0 & 3.26 & 59.76 & 1.4 & 88.9 & 1.28 & 20.08 & -4.12 \\
\hline Kuo & Nadowli & UW16 & 197.4 & 395.0 & 1.76 & 43.32 & 0.75 & 84.09 & 1.19 & 15.44 & -15.06 \\
\hline Monyupele & Lawra & UW17 & 218.0 & 435.0 & 3.45 & 68.47 & 2.02 & 99.46 & 2.08 & 27.12 & -17.67 \\
\hline Monyupele & Lawra & UW18 & 43.8 & 87.5 & 2.14 & 71.02 & 2.15 & 99.89 & 1.12 & 10.58 & -9.34 \\
\hline Chepuri & Jirapa-Lambussie & UW19 & 138.2 & 276.0 & 1.44 & 43.69 & 0.75 & 99.24 & 1.48 & 17.62 & -12.35 \\
\hline Billaw Pousi & Jirapa-Lambussie & UW20 & 215.0 & 431.0 & 0.91 & 28.34 & 0.37 & 75.67 & 0.96 & 14.67 & -4.13 \\
\hline Wahabu & Sissala & UW21 & 300.0 & 600.0 & 2.43 & 47.25 & 0.84 & 79.14 & 2.44 & 14.09 & -12.53 \\
\hline Jeffisi-Bosobelle & Sissala & UW22 & 564.0 & 1128.0 & 1.39 & 36.9 & 0.51 & 65.09 & -0.57 & 15.32 & -1.03 \\
\hline Tumu & Sissala & UW23 & 312.0 & 623.0 & 1.47 & 39.54 & 0.59 & 81.71 & 1.64 & 11.76 & -24.08 \\
\hline
\end{tabular}

All ionic concentrations are in milli-equivalents per litre (meq/L) except for \%Na, MAR and PI which are expressed in percentages $(\%)$ 
area have TDS ranging from 43.8 to $564 \mathrm{mg} / \mathrm{L}$ and can therefore be classified as "none" and "slight to moderate". This implies that the groundwater in the study is suitable for irrigation based on TDS values.

\section{Percentage sodium (\% Na)}

$\% \mathrm{Na}$ is an indication of the soluble sodium content of the groundwater and also used to evaluate $\mathrm{Na}$ hazard. In all natural waters, $\% \mathrm{Na}$ is a common parameter to assess its suitability for irrigation purposes since sodium reacts with the soil to reduce permeability (Janardhana Raju et al. 1992; Wilcox 1955). According to Fipps (2003), water with a $\% \mathrm{Na}$ greater than $60 \%$ may result in sodium accumulations that will cause a breakdown in the soil's physical properties. Excess $\mathrm{Na}$ combining with carbonate, leads to formation of alkali soils, whereas with chloride, saline soils are formed. Neither soil will support plant growth (Rao 2005). The $\% \mathrm{Na}$ of the groundwaters in the study area ranges from 28.34 to $71.02 \%$. The Wilcox (1955) diagram (Fig. 3) relating sodium percent and EC shows that $95.65 \%$ of the groundwater falls in the "Excellent to Good" range while the remaining $4.35 \%$ fall under the "Good to Permissible" range. This makes the groundwater in the study area suitable for irrigation purposes.

\section{Permeability index (PI)}

The classification of water for irrigation based on PI was suggested by Doneen (1964). This takes into consideration the $\mathrm{Na}^{+}, \mathrm{Ca}^{2+}, \mathrm{Mg}^{2+}$ and $\mathrm{HCO}_{3}{ }^{-}$contents of the soil. The PI values in the study area vary from 65.09 to 99.39 as shown in Table 2. Based on Doneen's chart and the USSL diagram classification, groundwater with PI greater than $75 \%(\mathrm{PI}>75 \%)$ are termed Class I, Class II $(25-75 \%)$

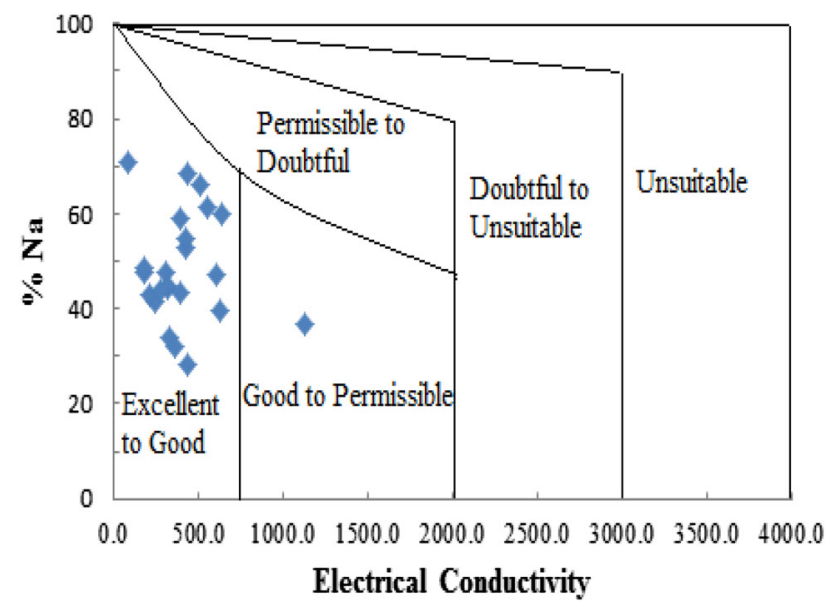

Fig. 3 Wilcox diagram showing the suitability of groundwater for irrigation and Class III $(<25 \%)$. Based on PI values, all the samples are Class I samples except for one which is Class II, representing 96.65 and $4.35 \%$, respectively. This makes the water very suitable for irrigation.

\section{Residual sodium carbonate ( $\mathrm{RSC})$}

Waters with high concentrations of $\mathrm{HCO}_{3}{ }^{-}$have the tendency to cause the precipitation of $\mathrm{Ca}^{2+}$ and $\mathrm{Mg}^{2+}$ as the water in the soil becomes more concentrated. As a result, the relative proportion of $\mathrm{Na}^{+}$in the water is increased in the form of sodium bicarbonate (Sadashivaiah et al. 2008). RSC values less than $1.25 \mathrm{meq} / \mathrm{L}(\mathrm{RSC}<1.25 \mathrm{meq} / \mathrm{L})$ are generally considered safe for irrigation. Water with an RSC between 1.25 and $2.5 \mathrm{meq} / \mathrm{L}$ is termed marginal and could be used with good irrigation management techniques and soil salinity monitored by laboratory analysis. Those with RSC values greater than $2.5 \mathrm{meq} / \mathrm{L}(\mathrm{RSC}>2.5 \mathrm{meq} / \mathrm{L})$ are said to be unsuitable for irrigation (Eaton 1950; Richards 1954). In this study, $56 \%$ of the samples are safe for irrigation, $34.78 \%$ are marginal and would require great care in its usage. The remaining $8.7 \%$ are unsuitable for use as irrigated water.

\section{Sodium adsorption ratio (SAR)}

Irrigation water containing large amounts of sodium is of special concern due to sodium's effects on the soil and poses a sodium hazard. Continued use of water having a high SAR leads to a breakdown in the physical structure of the soil. Sodium is adsorbed and becomes attached to soil particles. The soil then becomes hard and compact when dry and increasingly impervious to water penetration. Fine textured soils, especially those high in clay, are most subject to this action. Certain amendments may be required to maintain soils under high SARs. Calcium and magnesium, if present in the soil in large enough quantities, will counter the effects of the sodium and help maintain good soil properties (Fipps 2003). Groundwater for irrigation with a SAR value less than $10 \mathrm{meq} / \mathrm{L}$ (SAR $<10 \mathrm{meq} / \mathrm{L})$ are classified as "Excellent", those with SAR values between 10 and $18 \mathrm{meq} / \mathrm{L}$ are termed "Good" and "Doubtful" if the SAR value is between 18 and $26 \mathrm{meq} / \mathrm{L}$. "Unsuitable" refers to groundwater with a SAR value greater than $26 \mathrm{meq} / \mathrm{L}(\mathrm{SAR}>26 \mathrm{meq} / \mathrm{L})$ (Sadashivaiah et al. 2008; Todd 1980). Based on SAR values for the study area, all the groundwaters could be classified as excellent and would be suitable for irrigation. A plot of groundwater data on the US salinity diagram (Richards 1968), in which the EC is taken as salinity hazard and SAR as alkalinity hazard (Fig. 4), shows $13.04 \%$ of the samples fall within the low salinity-low sodium type of water (C1-S1) and $82.61 \%$ fall under 
Fig. 4 USSL diagram for classifying irrigation waters on the basis of SAR and EC as described by Richards (1968)

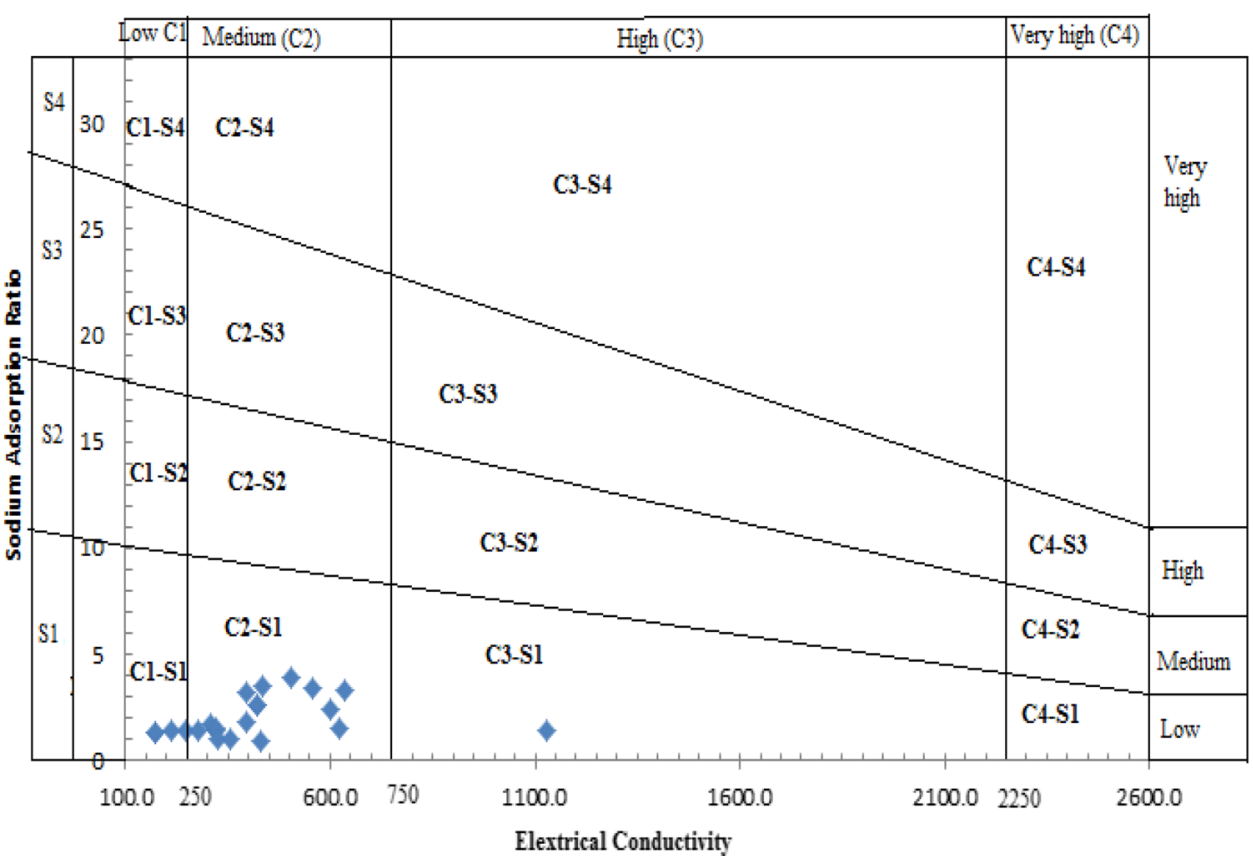

medium salinity-low sodium class (C2-S1). Only $4.35 \%$ (representing only one sample) of the samples fall within the high-salinity hazard-low sodium hazard class (C3-S1). This groundwater sample (C3-S1) is from a well in the Jeffisi-Bosobelle of the Sissala district. Groundwaters that fall within the C1-S1 and C2-S1 can be used for irrigation on all types of soil with little danger of the development of harmful levels of exchangeable sodium. However, C3S1 types of water could only be used to irrigate certain semi-tolerant crops (Ahamed et al. 2013).

\section{Magnesium adsorption ratio (MAR)}

Calcium and magnesium in most waters maintain a state of equilibrium. Raghunath (1987) and Gupta and Gupta (1987) suggest that high magnesium hazard value ( $>50 \%$ ) has an adverse effect on the crop yield as the soil becomes more alkaline. MAR results from this study shows that all the samples are well below $50 \%$ and as such suitable for irrigation.

\section{Kelly's ratio (KR)}

Kelly's ratio (KR) introduced by Kelly (1963) is an important parameter used in the evaluation of water quality for irrigation. This parameter is based the $\mathrm{Na}, \mathrm{Ca}$ and $\mathrm{Mg}$ levels in the groundwater. According to this classification, groundwater with a KR value greater than one $(\mathrm{KR}>1)$ is deemed unfit for irrigation. From this study, eight groundwater samples from six communities representing $34.78 \%$ of the total samples have values greater than 1 .
The areas with KR values above 1 are Silaa, Silaa Duasi and Yanyounyiri in the Wa Municipality, Wogu Newtown and Moyiri in the Nadowli district and Monyupele in the Lawra district. This suggests that groundwater from such towns are deemed unfit for irrigation based on Kelly's ratio.

\section{Chloro-alkaline indices (CAI)}

CAI gives an indication of ion exchange between ions in the groundwater and their host rock (Sastri 1994). A negative CAI value is an indication of exchange between $\mathrm{Na}+\mathrm{K}$ with $\mathrm{Ca}$ and $\mathrm{Mg}$. If there is no exchange between these parameters, a positive CAI value would be recorded. All the groundwaters in the study area recorded positive CAI values and therefore gives an indication of the occurrence of Base Exchange between $\mathrm{Na}$ and $\mathrm{K}$ in water with $\mathrm{Ca}$ and $\mathrm{Mg}$ in the host rocks.

\section{Conclusion}

The suitability of groundwater for irrigation in some selected areas of intensive farming in five districts of the Upper West region has been assessed with reference to internationally accepted standards. EC values in the study area show that the groundwater in the study area is excellent and good as such suitable for irrigation purpose. The groundwater in the study area is also within the class of none and Slight to moderate based on TDS classification. The Wilcox diagram also classifies the groundwater in 
the study area as excellent to good and good to permissible. The PI values based on Doneen's chart and USSL diagram shows that the groundwater falls under Class I and II, making the groundwater suitable for irrigation. The US Salinity diagram also reveals that majority of the groundwater fall within the low salinity-low sodium hazard and medium salinity-low sodium hazard class. However, one sample form Jeffisi-Bosobelle of the Sissala district fall within the high salinity-low sodium hazard class. This groundwater could therefore be used limitedly and carefully to irrigate only semi-tolerant crops. Evaluation of the suitability of the groundwater in the study area for irrigation based on KR also suggests that $34 \%$ of the samples are unfit for irrigation. Generally, groundwater in the study area is good for irrigation except for few instances which require special careful application.

Open Access This article is distributed under the terms of the Creative Commons Attribution License which permits any use, distribution, and reproduction in any medium, provided the original author(s) and the source are credited.

\section{References}

Aduah MS, Aabeyir R (2012) Land Cover Dynamics in Wa Municipality, Upper West Region of Ghana. Res J Environ Earth Sci 4(6):658-664 2012 ISSN: 2041-0492

Ahamed AJ, Ananthakrishnan S, Loganathan K, Manikandan K (2013) Assessment of groundwater quality for irrigation use in Alathur Block, Perambalur District, Tamilnadu, South India. Appl Water Sci 3:763-771. doi:10.1007/s13201-013-0124-z

Anayah F, Kaluarachchi JJ (2009) Groundwater Resources of Northern Ghana: Initial assessment of data availability. Utah State University

Ayers RS, Westcott DW (1985) Water quality for agriculture (No. 29): Food and Agriculture Organization of the United Nations, Rome, Italy

Carpenter SR, Caraco NF, Correll DL, Howarth RW, Sharpley AN, Smith VH (1998) Nonpoint pollution of surface waters with phosphorous and nitrogen. Ecol Appl 8(3):559-568

Doneen LD (1964) Notes on water quality in Agriculture Published as a Water Science and Engineering Paper 4001, Department of Water Science and Engineering, University of California

Eaton FM (1950) Significance of carbonate irrigation water. Soils Sci 69(2):123-133

Fianko JR, Nartey VK, Donkor A (2010) The Hydrochemistry of groundwater in rural communities within the Tema Disrict, Ghana. Environ Monit Assess 168:441-449

Fipps G (2003) Irrigation water quality standards and salinity management strategies. Texas Agricultural Extension Service, Texas A\&M University System, College Station, TX (USA). B-1667, 4-03, pp 1-19

Griffis RJ, Agezo FL (2000) Mineral Occurrences and Exploration Potential of Northern Ghana. Minerals Commission Report, Accra

Gupta SK, Gupta IC (1987) Management of saline soils and water. Oxford and IBH publication Co., New Delhi, p 399

Gyau-Boakye P, Tumbulto JW (2000) The Volta Lake and declining rainfall and stream flows in the Volta River Basin. Environ Dev Sustain 2:1-10
Hem JD (1985) Study and interpretation of the chemical characteristics of natural water (3rd edn): US Geological Survey WaterSupply Paper 2254, p 263

Hirdes W, Davis DW, Eisenlohr BN (1992) Reassessment of Proterozoic Granitoids Ages in Ghana on the Basis of U/Pb Zircon and Monazite Dating. Precambr Res 56(1-2):89-96. doi:10.1016/0301-9268(92)90085-3

Jain CK, Bandyopadhyay A, Bhadra AA (2009) Assessment of groundwater quality for drinking purpose, District Nainital Uttarakhand, India. Environ Monit Assess. doi:10.1007/ s10661-009-1031-5

Janardhana Raju N, Reddy TVK, Kotaiah BPT (1992) A study on seasonal variations of ground water quality in Upper Gunjanaeru River basin, Cuddapah District, Andhra Pradesh. Fresenius Environ Bull 1:98-103

Johnson G, Zhang H (1990) Classification of irrigation water quality. Oklahoma cooperative Extension fact sheets. (Available online at http://www.osuextra.com)

Kelly WP (1963) Use of saline irrigation water. Soil Sci 95:355-391

Kesse GO (1985) The mineral and rock resources of Ghana. A. A Balkema Press, Rotterdam, p 610

Key RM (1992) An introduction to the crystalline basement of Africa. Geological Society, London. Spec Publ 66:29-57

Kortatsi BK (1994) Groundwater utilization in Ghana. In: Future Groundwater Resources at Risk (Proceedings of the Helsinki Conference, June 1994). IAHS Publ. No. 222. Available at http:// iahs.info/redbooks/a222/iahs_222_0149.pdf (Accessed on 18th April, 2014)

Kurdi M, Tabasi S, Eslamkish T, Hezarkhani A (2013) Hydrogeochemical study to evaluate the suitability of water for irrigation purpose at Qareh sou catchment, North of Iran. Elixir Geosci 62:17536-17541

Leube A, Hirdes W, Mauer R, Kesse GO (1990) The early proterozoic Birimian supergroup of Ghana and some aspects of its associated gold mineralization. Precambr Res 46(1-2):139-165. doi:10. 1016/0301-9268(90)90070-7

Little J, Kalischuk A, Gross D, Sheedy C (2010) Assessment of Water Quality in Alberta's Irrigation Districts. Alberta Agriculture and Rural Development, Alberta, Canada

Matthess G (1982) The properties of groundwater. Wiley, New York, p 406

Michael AM (1992) Irrigation theory and practices. Vikash Publishing House Pvt. Ltd., New Delhi, pp 686-740

Namara RE, Awuni JA, Barry B, Giordano M, Hope L, Owusu ES, Forkuor G (2011) Small holder shallow groundwater irrigation development in the Upper East Region of Ghana. International Water Management Institute, Colombo, Sri Lanka, p 35 (IWMI Research Report 143). doi: 10.5337/2011.214

Nude PM, Arhin E (2009) Overbank sediments as appropriate geochemical sample media in regional stream sediment surveys for gold exploration in savannah regions of Northern Ghana. J Geochem Explor 103(1):50-56. doi:10.1016/j.gexplo.2009.06.005

Quist LG, Bannerman RR, Owusu S (1988) Groundwater in rural water supply in Ghana In: Ground Water in Rural Water Supply, Report of the West African Sub-Regional Workshop held in Accra, Ghana, 20-24 October 1986, UNESCO Technical Documents in Hydrology, Paris, pp 101-126

Raghunath HM (1987) Groundwater. Wiley Eastern Ltd., New Delhi, pp 344-369

Rao NS (2005) Seasonal variation of groundwater quality in a part of Guntur district, Andhra Pradesh, India. Environ Geol 49:413-429

http://www.ghanadistricts.com/reg-info.asp?RegionID=6. Retrieved $25 / 04 / 2014$

Richards LA (1954) Diagnosis and improvement of saline alkali soils: agriculture, handbook. US Department of Agriculture, Washington DC, vol 160, p 60

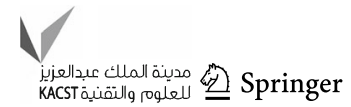


Richards LA (1968) Diagnosis and Improvement of Saline and Alkali Soils, US Dept Agriculture Handbook \# 60, Washington DC, USA

Sadashivaiah C, Ramakrishnaiah CR, Ranganna G (2008) Hydrochemical analysis and evaluation of groundwater quality in Tumkur Taluk, Karnataka State, India. Int J Environ Res Public Health 5(3):158-164

Salifu M, Yidana SM, Osae S, Armah YS (2013) The influence of the unsaturated zone on the high fluoride contents in groundwater in the Middle Voltaian Aquifers-the Gushegu District, Northern Region of Ghana. J Hydrogeol Hydrol Eng 2:2

Sastri JCV (1994) Groundwater chemical quality in river basin. Hydrogeochemical facies and hydrogeochemical modeling. Lecture notes-Refresher course conducted by school of Earth Science. Bharathidasan University. Trichirapalli, Tamilnadu, India

Taylor PN, Moorbath S, Leube A, Hirdes W (1992) Early Proterozoic Crustal Evolution in the Birimian of Ghana: Constraints from Geochronology and Isotope Geology. Precambr Res 56(1-2): 77-111. doi:10.1016/0301-9268(92)90086-4
Todd DK (1980) Groundwater hydrology. John Wiley and Sons Inc., New York, pp 10-138

UCCC (University of California Committee of Consultants) (1974) Guidelines for interpretations of water quality for irrigation. University of California Committee of Consultants, California, USA

USGS (US Geological Survey) (1948) Inventory of published and unpublished chemical analyses of surface waters in the western United States. Notes on hydrological activities. Bul. No. 2 (Processed)

USSL (US Salinity Laboratory) (1954) Diagnosis and improvement of saline and alkaline soils. Agriculture Handbook No. 60 USDA, p 160

WHO (2005) International standards for drinking water. World Health Organization, Geneva

Wilcox LV (1955) Classification and use of irrigation waters, US Department of Agriculture. Circ. 969. Washington, DC

Yidana SM, Yidana A (2009) Assessing water quality using water quality index and multivariate analysis. Environ Earth Sci 59:1461-1473 